\title{
マイコンによる直流電動機の適応制御
}

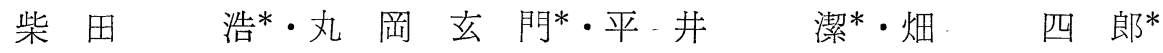

\section{Adaptive Control of a DC Motor Using a Microcomputer}

Hiroshi Shibata*, Genmon Maruoka*, Kiyoshi Hira** and Shiroh Hata*

1. 緒言

マイクロコンピュータ（マイコン）のめざましい発 展により, 複雑な制御アルゴリズムも安価浪実現可能 となってきた．とのような背景から本論文では，慣性 負荷が変化する直流モータの速度制御に，マイコンに よる適応制御を適用した結果を述べる。乙れは，連続 系の制御対象に対して離散時間モデル規範適応制御を 行ったあのである.

直流電動機のモデル規範適応制御には，Courtiol ${ }^{12 ，}$ 田村ら ${ }^{233)}, \mathrm{Naitoh}{ }^{4)}$ の報告があるが，前 2 者は適応制 御機構を連続系すなわちアナログ回路で実現したすの である. Naitoh のあのは離散時間適応制御方式を用 いているが，電気回路（との応答は機械系に比へてきき わめて速いので本論文では無視している）に対するむ のであり，機械系に対しては適応制御を行っておら ずまたディジタルシミュレーションによる結果のみ で実機運転は行っていない。

以下では，はじめに連続系のディジタル制御に適し た離散時間モデル規範適応制御アルゴリズムについて 述べ，その後それを用いた直流電動機の適応制御に移 る.

\section{2. 離散時間適応アルゴリズム}

離散形モデル規範適応制御アルゴリズムとしては, 現在まで種々のものが提案されているが5566)，アルゴ リズムの計算時間が無視できない場合には，それらを そのまま連続系の制御対象に適用できない，そこでこ こでは文献 6)のものを改良したつぎのようなアルゴ リズムを用いた。

†第 22 回計測自動制御学会学術講演会で発表 (昭 $58 \cdot 7$ )

* 大阪府立大学工学部 堺市百舌鳥梅町 4-804

* College fo Engineering, University of Osaka Prefecture, Sakai

(Received September 28, 1984)

(Revised December 8, 1984)
制御対象およびモデルはつぎのように離散時間形式 で表わされるむのとする.

$$
\begin{aligned}
& y(k)=\frac{q^{-1} b_{0} B\left(q^{-1}\right)}{A\left(q^{-1}\right)} u(k) \\
& y^{M}(k)=\frac{q^{-1} B^{M}\left(q^{-1}\right)}{A^{M}\left(q^{-1}\right)} u^{M}(k)
\end{aligned}
$$

ここで $q^{-1}$ は遅延オペレータ, $y(k), y^{M}(k)$ は出力, $u(k), u^{M}(k)$ は入力であり,さらに

$$
\begin{aligned}
& A\left(q^{-1}\right)=1+a_{1} q^{-1}+\cdots+a_{n} q^{-n} \\
& B\left(q^{-1}\right)=1+b_{1} q^{-1}+\cdots+b_{n-1} q^{-n+1} \\
& A^{M}\left(q^{-1}\right)=1+a_{1}^{M} q^{-1}+\cdots+a_{n}^{M} q^{-n} \\
& B^{M}\left(q^{-1}\right)=b_{0}^{M}+b_{1}^{M} q^{-1}+\cdots+b_{n-1}^{M} q^{-n+1}
\end{aligned}
$$

てれに対してつぎのような適応アルゴリズムを用い る.

$$
\begin{aligned}
& \varphi^{T}(k)=[y(k-1), \cdots, y(k-n), u(k), \cdots, u(k-n)] \\
& e(k)=y(k)-y^{M}(k) \\
& \hat{\theta}(k)=\hat{\theta}(k-2)+\frac{a(k) \varphi(k-2) e(k-1)}{1+\varphi^{T}(k-2) \varphi(k-2)} \\
& \quad(0<a(k)<2) \\
& \varphi^{T}(k) \hat{\theta}(k)=y^{M}(k+1)
\end{aligned}
$$

(3)式の $\varphi(k)$ と (5)式の $\hat{\theta}(k)$ は $(2 n+1)$ 次元べ クトルである. 適応制御入力 $u(k)$ は $(6)$ 式より決定 されるが，乙のとき従来のむの的と異なり同時刻の出 力 $y(k)$ を用いていない. また(5)式の右辺に捄いて む $e(k)$ の代りに $e(k-1)$ を用いこてであ $y(k)$ の使 用を避けている. このようにして連続系のディジタル 制御における計算時間遅れの問題を回避している。 のアルゴリズムの安定性の証明は付録に示す.

\section{3. 適応系の構成と実験結果}

Fig. 1 は適応制御系の構成図である.直流電動機の 速度はタコジェネレータによって検出され，アナログ フィルタによって雑音除去されてのち, 12 ビットの $\mathrm{A} / \mathrm{D}$ 変換器を通して適応制御器であるマイコンに取 


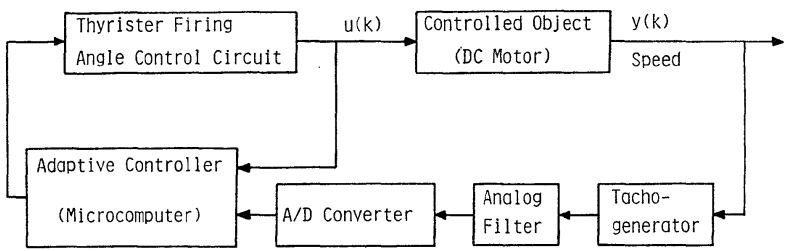

Fig. 1 Control system structure

り込まれる.乙れは 8 ビットマイコンであり，適応ア ルゴリズムによる制御入力の計算を実数で行い，その 結果を 16 ビットの整数值に変換してサイリスタ点弧 角制御回路に送る。乙こでは全波整流回路のサイリス 夕の点弧角を変化させるととにより, 電動機の電機子 電流を制御する。

制御対象は $10 \mathrm{~W}$ の直流サーボモータであり，その 伝達数 $G(s)$ は速度制御であるから,

$$
G(s)=\frac{K}{1+T S}
$$

で与えられる. 時定数 $T$ のおおようう值は，無負荷， 軽負荷, 重負荷の 3 種に対してそれぞれ $0.17,0.68$,

\section{8 秒である.}

モデルの伝達関数 $G^{M}(s)$ は，実際は設計者が仕様 をみたすように決定するものであるが，乙こでは仮り に次式とした。

$$
G^{M}(s)=\frac{1}{s^{2}+s+0.5}
$$

サンプル周期はマイコンの計算所要時間を考えて 0.3 秒とした.

(8)式に零次ホールドを縦続させて $Z$ 変換し，それ をモデルのパルス伝達関数とし， 2 節の適応アルゴリ ズムによる制御を行った.

Fig. 2 はモデルの入力をステップ入力としたとき の出力の芯答である. ここで $(5)$ 式中の $a(k)$ は $a(k)$ $=0.5$ とした. 図中, 曲線 $(\mathrm{d})$ は規範モデルの出力 $y^{M}(k)$ すなわち所望の応答であり，乙れに一致する 応答が䛊差零の最良のあのとなる，曲線( a )，(b)， （c）はそれぞれ無負荷, 軽負荷, 重負荷に対する出力 态答 $y(k)$ であり, 重負荷に対する応答はかなり遅く なるが，適応制御が安定に行われているととがわか る、このとき立上りが遅れるのは静止まさつにより, 電機子電流がある程度大きくならないと電動機が回転 しはじめないためである． $y^{M}(k)$ をステップ関数にす ればての静止まさつによる遅れは消滅する。

Fig. 3 は適応制御の応答改善をはかるために，非 再帰形フィルタを用いた結果である。すなわち(5)式 右辺の $e(k-1)$ の代りに次式の $e_{f}(k-1)$ を用いる ${ }^{5)}$.

$$
e_{f}(k-1)=\left(1-0.2 q^{-1}\right)^{3} e(k-1)
$$

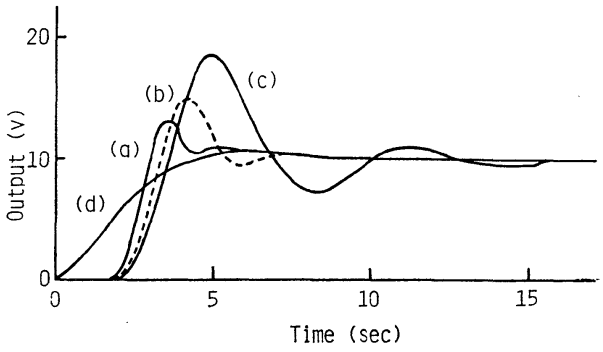

Fig. 2 Responses of the adaptive control system (a) No load (b) Light load (c) Heavy load (d) Model

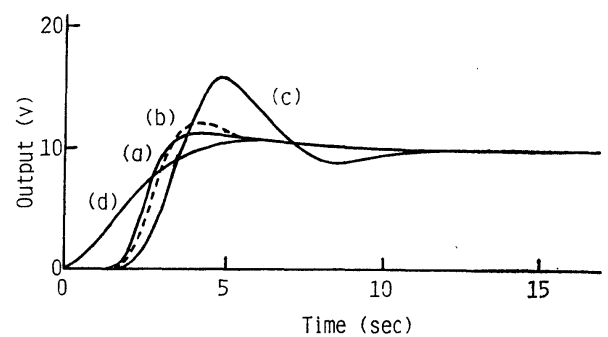

Fig. 3 Responses with filter

(a) No load (b) Light load

(c) Heavy load (d) Model

このときは $a(k)=1.0$ とした. Fig. 2 に比べると， 行き過ぎ量, 整定時間ともに 3 種の負荷すべてについ てかなり改善されているととがわかる.

\section{4. 結言}

連続系の制御対象に対する離散形モデル規範適応制 御の一応用例として, 負荷が変化する直流電動機の適 応制御を試みた。とこで用いたアルゴリズムは最む簡 単なあのであり，計算時間が短かくマイコン応用に適 している，ただ収束性はあまりよくないと言われてい るが, フィルタの導入によってかなり改善されること がわかった。

\section{《付 録》}

安定性の証明には，(1)式の制御対象に対しつぎの 仮定が必要である.

a) $n$ の上限は既知である.

b) $B(z)$ のすべての零点は $z$ 平面における単位円 の外部にある.

Egardt の変換多項式 ${ }^{5)}$

$$
T\left(q^{-1}\right) A^{M}\left(q^{-1}\right)=A\left(q^{-1}\right) R\left(q^{-1}\right)+q^{-1} S\left(q^{-1}\right)
$$

において $\quad T\left(q^{-1}\right) A^{M}\left(q^{-1}\right)=1, \quad R\left(q^{-1}\right)=1+r_{1} q^{-1}$ と おき， $S\left(q^{-1}\right)$ の多項式をその定数項が 0 となるように 
選ぶと，(1)式は(3)式を用いてつぎのようにかけと同じである.

$ろ^{5)}$.

$$
\varphi^{T}(k) \theta_{0}=y(k+1)
$$

ただしベクトル $\theta_{0}$ は $(1),(\mathrm{A} .1)$ 式より決まる係 数パラメータの真值である.

$$
\tilde{\theta}(k)=\hat{\theta}(k)-\theta_{0}
$$

とすると，(5)，(6)，(A.2)式を用いて

$\|\tilde{\theta}(k)\|^{2}-\|\tilde{\theta}(k-2)\|^{2}$

$$
\begin{aligned}
= & -2 a(k) \frac{\tilde{\theta}(k-2) \varphi(k-2) \varphi^{T}(k-2) \tilde{\theta}(k-2)}{1+\varphi^{T}(k-2) \varphi(k-2)}+a^{2}(k) \cdot \\
& \frac{\varphi^{T}(k-2) \varphi(k-2) \varphi^{T}(k-2) \tilde{\theta}(k-2) \varphi^{T}(k-2) \tilde{\theta}(k-2)}{\left(1+\varphi^{T}(k-2) \varphi(k-2)\right)^{2}} \\
= & \frac{a(k) \tilde{\theta}^{T}(k-2) \varphi(k-2) \varphi^{T}(k-2) \tilde{\theta}(k-2)}{1+\varphi^{T}(k-2) \varphi(k-2)} . \\
& \left(-2+\frac{a(k) \varphi^{T}(k-2) \varphi(k-2)}{1+\varphi^{T}(k-2) \varphi(k-2)}\right) \\
\leq & 0 \\
\text { このあとの証明は Goodwin ら } & \text { (5) の定理 5.1 のむの }
\end{aligned}
$$

\section{参 考 文 献}

1) B. Courtiol: Applying Model Reference Adaptive Techniques for the Control of Electromechanical Systems, Preprints of IFAC '75 58.2 (1975)

2) 田村, 市川, 小滰, 天野：クーロン摩擦を受ける直流市 一ボ系の適応制御系の構成, 計測自動制御学会論文集, 20-3, 227/232 (1984)

3) 田村, 市川, 小滝, 天野: クーロン摩擦を受ける直流サ 一ボ系の適応制御, 計測自動制御学会論文集, 20-7, 663/ 665 (1984)

4) H. Naitoh: Model Reference Adaptive Control for Adjustable Speed Motor Drives, IPEC Tokyo '83, 1706/1716 (1983)

5) B. Egardt: Stability of Adaptive Controllers, Springer (1979)

6) G.C. Goodwin, P. J. Ramadge and P.E. Caines: Discrete-Time Multivariable Adaptive Control, IEEE Trans. on Automatic Control, AC-25-3, 449/ 456 (1980) 